
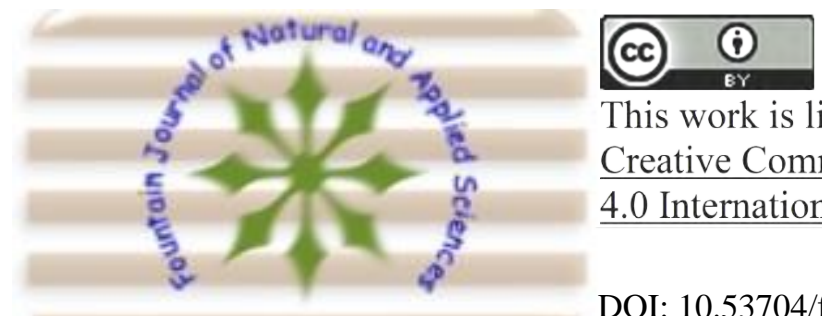

This work is licensed under

Creative Commons Attribution

$\underline{4.0 \text { International License. }}$

DOI: 10.53704/fujnas.v6i1.159

A publication of College of Natural and Applied Sciences, Fountain University, Osogbo, Nigeria.

Journalhomepage:www.fountainjournals.com

ISSN:2354-337X(Online),2350-1863(Print)

\title{
Nutrient and Antinutrient Compositions of Some Edible Insect Species in Northern Nigeria
}

\author{
*Oibiokpa, F.I., Akanya, H.O., Jigam, A.A., Saidu, A.N. \\ Department of Biochemistry, Federal University of Technology, P.M.B 65, Minna, Nigeria.
}

\begin{abstract}
Nutrient and Antinutrient Compositions of Some Edible Insect Species in Northern Nigeria. The nutrient and antinutrient compositions of Moth caterpillar (Cirinaforda), Termite (Macrotermes nigierensis), Cricket (Gryllus assimilis) and Grasshopper (Melanoplus foedus) were determined. The proximate compositions were analysed using the methods of the Association of official Analytical Chemist while minerals were estimated using Atomic absorption spectrophotometry. The fatty acid profile of the oils extracted from the insects was determined by Gas chromatography/Mass spectrometry method. The vitamin and antinutrient composition of these insects were determined using standard laboratory methods. Termite was found to contain the highest amounts of moisture $(4.50 \pm 0.12 \%)$, ash $(8.00 \pm 0.12 \%)$ and fats $(40.83 \pm 0.03 \%)$ while moth caterpillar was found to have the highest amount of crude fibre and carbohydrate $(13.25 \pm 0.21 \%)$. Grasshopper was found to have the highest amount of crude protein $(75.08 \pm 0.91 \%)$ while termite contained the least amount of protein $(43.75 \pm 0.03 \%$ ). The Metabolisable energy of the insects were generally high and ranged from $392.83 \pm 0.35 \mathrm{kcal} / 100 \mathrm{~g}$ in grasshopper to $554.00 \pm 3.40 \mathrm{kcal} / 100 \mathrm{~g}$ in termite. Potassium was the most abundant mineral in all the insects. Palmitic acid was found in high amounts in termite (25.78\%), moth caterpillar $(20.78 \%)$ and grasshopper $(21.15 \%)$ while cricket had the lowest palmitic acid content (1.69\%). The essential fatty acids found in the insects were linolenic acid and linoleic acid. Moth Caterpillar had the highest amount of linolenic acid (28.69\%) while grasshopper had the highest amount of linoleic acid $(17.2 \%)$. Vitamin $E$ was found to be the most abundant vitamin while vitamin $B_{2}$ was the least abundant in all the insects analysed. Antinutrients in all the insects were within permissible limits and may not pose any threat to their usage as sources of food. These results have thus justified the consumption of these insects as food.
\end{abstract}

Keywords: Edible insects, Nutrients, Antinutrients, Vitamin, Mineral, Fatty acids

\section{Introduction}

Insects have served as traditional foods among indigenous people, especially in Africa, Asia and Latin America (van Huis et al., 2013). Insects are very abundant in nature and rank among the most successful animals on earth but are seasonally available and so cannot be part of the diet all through the year. Insects also serve as source of income for some people in Nigeria and Africa at

*Corresponding author: +2348035917441

Email address: florence@futminna.edu.ng 
large, as these insects are harvested from thewild, gathered and sold in markets. The use of insects as food has not been widely accepted in most developed countries of the world and has reduced drastically with colonisation and globalization of Africa, Asia and America (Heinrich and Prieto, 2008; Kagezi et al., 2010). Hundreds of species of insects have been used as food. Locust, termites, ants, grasshoppers, weevils, beetles, crickets, among commonly consumed insects in Nigeria (Alamu et al., 2013). Studies show that most Nigerians have directly or indirectly consumed edible insects although consumption of insects is more prevalent in rural than urban areas (Ekop et al., 2010). Many species of insects such as aphids, ants and grasshoppers are eaten as eggs or in their adult forms. Other insects are eaten in their wormlike larval stage, these immature insects include beetle grubs and moth caterpillars. Some insects are eaten raw while others are eaten fried or roasted.

Moth caterpillar (Cirina forda) is a pest of the sheabutter tree. Moth caterpillars dig into the soil of host plant to pupate. It is one of the widely eaten insects in southern Nigeria (Osasona and Olaofe, 2010). The larva is a delicacy, served as snack or taken with carbohydrate rich foods (Omotoso,2006).Grasshoppers affect man as pest, destroying man's valuable materials and crops. The grasshopper is a seasonal pest which has a large population during the dry season in northeastern Nigeria and has been reported to be eaten in other parts of Nigeria (Iduwu and Modder, 1996). Grasshoppers, also known as dessert shrimps, are usually picked from grasses and bushes late in the night or early in the morning before they become active. They are dewinged, seasoned with salt and fried to make a very tasty snack (Bamaiyi and Aniesona, 2012). Termites are the most commonly eaten insects in Africa. The large winged termites are usually collected as they emerge from the nest on their mating flights at the beginning of the rainy season. They are strongly attracted to light, a behavior used in capturing them (Defoliart, 1995). Crickets are large insects that live underground where they feed on the roots of plants in the soil. They live in holes in the field. The hole is usually covered with a small heap of soil which the cricket dug from the earth to make its home. Crickets usually come out of their holes at night when they can be handpicked. In West Africa, some children dig crickets from their holes, roast and eat them (Adeyeye and Awokunmi, 2010).

Although insects are generally regarded as pest to humans, they represent the cheapest source of animal protein as compared to conventional sources of animal protein. Defoliart, (2002) reported that the level of protein and fat in some insects is generally higher than traditional sources of animal protein. The protein content of some insects have been reported to vary between $13 \%$ to $77 \%$ (Kourimska and Adamkova, 2016) showing that insects contain higher amounts of protein compared to conventional sources of animal proteins like beef (55.0\%) (van Huis et al., 2013). Several authors have also showed that insects are good sources of vitamins and minerals (Defoliart et al., 2009). Therefore, insects may be a promising foodstuff for combating malnutrition problems ravaging, most particularly, the developing parts of the world. The rising human population is continuously driving up the demand for food; there is also a concomitant reduction in the availability of land resources to produce food. Reports have shown that 795 million people are undernourished constituting about $11 \%$ of the world's population with $98 \%$ of them living in developing regions (FAO, 2015). In Developing Countries protein energy malnutrition has continued to be a serious problem due to high prices of food particularly foods of animal origin. Conventional sources of proteins are limited in supply and relatively expensive in Nigeria (Jacob et al., 2013). Protein energy malnutrition and also micronutrient deficiencies have been implicated in increased child mortality, maternal mortality and diseases associated with various nutritional deficiencies. Malnutrition is said to have severe consequences on human well-being by aggravating poverty, irreversible mental damages, poor growth among children, decreased future earnings of individuals and decreased growth of a country resulting in decrease in gross national product due to short life span (FAO, 2008). 
To overcome malnutrition there is a need for increased research on alternative and cheaper sources of food nutrients; these researches will provide more information and encourage the use of these foods. To overcome nutritional deficiencies there is also a need for dietary diversification to provide all the nutrients required for maintaining health and general wellbeing of individuals.

The nutritional benefits of insects have been overlooked, therefore this study is aimed at providing data on the nutrient composition of insects and this may encourage the use of insects as food. Antinutrients in food cause deleterious effects on the nutritional status of food. Chronic exposure to these antinutrients could be harmful to humans. Paucity of literature data on the nutritional value of insects has not encouraged the use of insects as food.

\section{Materials and Methods \\ Materials}

The following insects were collected and identified by an Entomologist, Dr I.K. Olayemi of the Department of Biological Sciences, Federal University of Technology, Minna, Niger State, Nigeria:

(a) Termites (Macrotermes nigeriensis)

(b) Cricket (Gryllus assimilis)

(c) Grasshopper (Melanoplus foedus)

(d) Moth caterpillar ( Cirina forda)

The crickets were handpicked from Tyomu village in Guma local Government of Benue State, Termites were obtained from Wakpa Village, Lafia Central Local Government of Nassarawa State, Moth Caterpillar was purchased from Akurba Village in Gboko Local Government of Benue State, while grasshoppers were purchased from Katsina Central Market, Katsina State.

The insects were sun dried for one week, powdered using pestle and mortar. The samples were stored in plastic containers for analysis.

\section{Methods}

\section{Proximate analysis}

The moisture, crude lipid, crude protein, crude fibre, ash and total carbohydrate contents were determined using the methods of the Association of official Analytical Chemist (AOAC) (1990).

\section{Determination of moisture content}

Two grams (2g) of insect sample was weighed into a clean and dried crucible. The crucible with its content was transferred into an oven and dried at a temperature of $80^{\circ} \mathrm{C}$ for 2 hours and $100^{\circ} \mathrm{C}$ for another 4hours until a constant weight was obtained. The sample was allowed to cool in a desiccator and the dry weight of sample plus crucible was noted. The \% moisture was calculated as follows:

$\%$ Moisture $=\frac{\mathrm{W} 2-\mathrm{W} 3}{\mathrm{~W} 2-\mathrm{W} 1} \times 100$

$W_{1}$ Initial weight of empty crucible

$W_{2}=$ Weight of crucible + sample before drying

$W_{3}=$ Final weight of crucible + sample after drying.

Determination of ash content

Two grams (2g) of insect sample was weighed into a pre -weighed porcelain crucible. The crucible with its content was placed in a pre-heated Muffle furnace at $550^{\circ} \mathrm{C}$ and allowed to char for 2 hours until a white ash was obtained. The sample was allowed to cool in a desiccator and reweighed. The weight of the ash was expressed as a percentage of the initial weight of the sample.

$\%$ Ash $=\frac{\text { weight of ash }}{\text { sample weight }} \times 100$

$=\frac{\mathrm{W} 3-\mathrm{W} 1}{\mathrm{~W} 2-\mathrm{W} 1} \times 100$

Where $W_{1}=$ weight of empty crucible

$W_{2}=$ Weight of crucible + sample before drying and I or ashing and

$W_{3}=$ Weight of crucible + Ash

Determination of crude fibre content

Two grams (2g) of insect sample was defatted with petroleum ether. The sample was then transferred into $250 \mathrm{~cm}^{3}$ Erlenmeyer flask and boiled under reflux for 30 minutes with $200 \mathrm{ml}$ of a solution containing $1.25 \% \quad \mathrm{H}_{2} \mathrm{SO}_{4}$ solution. The content of the flask was filtered and subsequently washed with boiling water until the washings were no longer acid. The sample was transferred into the flask and was boiled for 30 minutes with $200 \mathrm{ml}$ solution, containing $1.25 \% \mathrm{NaOH}$ solution. The residue was filtered and washed thoroughly until the washings were no longer alkaline. The sample was transferred to a crucible and was dried in an oven at $105^{\circ} \mathrm{C}$. The crucible with its content was then incinerated at $550^{\circ} \mathrm{C}$ for 30 minutes, cooled and 
weighed. The loss in weight was expressed as a percentage of the initial weight of the sample. $\%$ Crude fibre

$=\frac{\text { (weight of crucible+sample before ignition })-(\text { weight of cruible }+ \text { Ash })}{\text { intitial }} \times 100$

\section{Determination of crude protein content}

The Kjedahl method was used to determine the crude protein content of each insect sample. Two grams of sample was weighed, wrapped in Whatman filter paper (No.1) and put in the Kjedahl digestion flask. Concentrated sulphuric acid $(10 \mathrm{ml})$ was added. Catalyst mixture $(0.5 \mathrm{~g})$ containing sodium sulphate $\left(\mathrm{Na}_{2} \mathrm{SO}_{4}\right)$, copper sulphate $\left(\mathrm{CuSO}_{4}\right)$ and selenium oxide $\left(\mathrm{SeO}_{2}\right)(10: 5: 1)$ were added into the flask to facilitate digestion. Four pieces of antibumping granules were added. The flask was transferred to a Kjeldahl digestion apparatus for 3 hours until the content turned light green. The digested sample was cooled and diluted with distilled water to $100 \mathrm{ml}$ in standard volumetric flask. Aliquot $(10 \mathrm{~m} 1)$ of the diluted solution with $10 \mathrm{ml}$ of $45 \%$ sodium hydroxide was then transferred to a Markham distillation apparatus and distilled into $10 \mathrm{ml}$ of $2 \%$ boric acid containing 4 drops of methyl red indicator until about $70 \mathrm{ml}$ of distillate was collected. The distillate was then titrated with $0.01 \mathrm{~N}$ hydrochloric acid until a grey colour was observed.

Percentage Nitrogen $=\frac{(\mathrm{a}-\mathrm{b}) \times 0.01 \times 14 \times \mathrm{V} \times 100}{\mathrm{~W} \times \mathrm{C}}$

Where:

a. = Titre value of the digested sample

b. = Titre value of blank sample

v. $\quad=\quad$ Volume after dilution $(100 \mathrm{ml})$

W. = Weight of dried sample $(\mathrm{mg})$

C. $=$ Aliquot of the sample used $(10 \mathrm{ml})$

14. $=$ Nitrogen constant in mg.

$\%$ Protein $=\%$ Nitrogen $\times 6.25$ (Conversion factor).

\section{Determination of crude lipid}

The crude lipid content of the insect sample was determined using the method described by AOAC (1990). Five grams of insect sample was taken into a thimble of known weight $\left(W_{1}\right)$. The weight of the thimble and sample was taken $\left(W_{2}\right)$. The thimble with the sample was placed in a Soxhlet extractor. An aliquot $(300 \mathrm{ml})$ of petroleum ether was poured into a $500 \mathrm{ml}$ round bottom ground joint flask, which was placed on a heating mantle. The heating and extraction continued for 24hours, after which the thimble with content was removed dried in an oven at $50^{\circ} \mathrm{C}$ for 24 hours, cooled in a dessicator and weighed $\left(W_{3}\right)$. The \% lipid content of each sample was calculated as follows:

$\%$ Lipid $=\frac{100(W 2-W 3)}{W 2-W 1}$

\section{Carbohydrate content determination}

Total carbohydrate content was determined by the difference as described by Nielsen (2002). The total amount of crude protein, crude fat, moisture and ash of each of the samples was added and subtracted from 100. The value obtained was the percentage carbohydrate content of the samples.

$\%$ Carbohydrate $=100-(\%$ moisture $+\%$ ash + $\%$ protein + \%fat)

\section{Determination of metabolisable energy}

Metabolisable energy of the sample was calculated using Atwater factors. The value of protein content of each sample was multiplied by 4 , that of lipid was multiplied by 9 and that of total carbohydrate multiplied by 4 . The sum of these values was expressed as $\mathrm{Kcal} / 100 \mathrm{~g}$.

\section{Determination of mineral content}

The minerals were extracted using dry ashing method as described by Nielsen (2002). One gram (1g) of each sample was weighed into glazed, porcelain crucibles and sample was ashed for $2 \mathrm{hrs}$ at $550^{\circ} \mathrm{C}$ and allowed to cool. The ash was transferred into a $250 \mathrm{ml}$ beaker, to which $15 \mathrm{ml}$ of concentrated hydrochloric acid and $5 \mathrm{ml}$ of concentrated nitric acid were added. The beaker was placed on a hotplate set at $100^{\circ} \mathrm{C}$ till the acid evaporated to dryness. An aliquot $(10 \mathrm{ml})$ of distilled water was added to the beaker and sample filtered into a $100 \mathrm{ml}$ volumetric flask and made up to the mark. The mineral content of the digested sample was analysed using atomic absorption spectrophotometer -6800 Shimadzu.

\section{Determination of fatty acid composition of oils}

The fatty acid composition of the sample was determined using Gas chromatography/Mass spectrometry. Oil extracted from sample was methylated by dissolving $0.2 \mathrm{~g}$ of the oil with $6 \mathrm{ml}$ of methanolic $\mathrm{NaOH}$ (2g NaOH in $100 \mathrm{ml}$ methanol) in a 
conical flask. This was refluxed for 10minutes. An aliquot $(10 \mathrm{ml})$ of $n$ hexane, was added to the mixture, refluxed for 2 minutes then cooled. A known volume $(10 \mathrm{ml})$ of distilled water was added and the lower aqueous layer separated from methylated oil. $\mathrm{CCl}_{4}$ was then added to remove excess water from the methylated oil. The methylated oil was then dissolved in pure hexane and introduced into the injector of GC/MS - gas chromatographic system (GCMS - QP 2010) at an injection temperature of $250^{\circ} \mathrm{C}$ using helium as a carrier gas at a pressure of $100.2 \mathrm{kPa}$.

The fatty acids were eluted as peaks whose retention times were measured by the mass spectrophotometer detector and compared with those of known standards. Individual fatty acids were identified using known standards (Onwuka, 2005).

\section{Vitamin analysis}

The vitamin $A, E, C, K, B_{2}$ and $B_{12}$ contents of the insect samples were determined using various standard analytical procedures.

\section{Determination of vitamin $A$}

Vitamin $A$ content was determined by the method described in the Marck index (2001). Two gram (2g) of insect sample was weighed into a flat bottom flask and $10 \mathrm{ml}$ of distilled water was added to the sample. Twenty five millilitre $(25 \mathrm{ml})$ of $0.5 \mathrm{M}$ alcoholic $\mathrm{KOH}$ solution was then added. The mixture was heated on a water bath for 1 hour and allowed to cool and $30 \mathrm{ml}$ of water was added. The hydrolysate obtained was transferred into a separatory funnel. The solution was extracted three times with $250 \mathrm{ml}$ of chloroform. Two grams (2g) of anhydrous $\mathrm{Na}_{2} \mathrm{SO}_{4}$ was added to the extract to remove any trace of water. The mixture was then filtered into $100 \mathrm{ml}$ volumetric flask and made up to mark with chloroform. Standard solution of Vitamin A of range $0-50 \mu \mathrm{g} / \mathrm{ml}$ was prepared by dissolving $0.003 \mathrm{~g}$ of standard Vitamin $A$ in $100 \mathrm{ml}$ of chloroform. Absorbances of sample and standards were read on the spectrophotometer (MetrohmSpectronic 21D Model) at a wavelength of $328 \mathrm{~nm}$ and vitamin $A$ content calculated.

Vitamin $A$ in $\mu g / 100 g=$ Absorbance of sample $\times$ Gradient factor $\times$ Dilution factor weight of sample

\section{Vitamin E determination}

Vitamin $E$ content was determined by the method described in the Marck index (2001). One gram (1g) of insect sample was weighed and $10 \mathrm{ml}$ of methanol was added. The sample was homogenised and then filtered. A known volume $(0.4 \mathrm{ml})$ of the extract was taken and $7.6 \mathrm{ml}$ of colour developer (containing sodium dihydrogen phosphate $(0.84 \mathrm{~g})$, Ammonium molybdate $(1.24 \mathrm{~g}), \mathrm{H}_{2} \mathrm{SO}_{4}(8.15 \mathrm{ml})$ and $250 \mathrm{ml}$ methanol) was added to the sample. A known volume $(0.4 \mathrm{ml})$ of methanol was then added to the sample. The sample was incubated at $90^{\circ} \mathrm{C}$ for 1 hour. The absorbance of the sample was read at $695 \mathrm{~nm}$ using Spectronic 21D spectrophotometer. Concentration of vitamin $E$ was extrapolated from standard curve that was prepared.

\section{Vitamin $B_{12}$ determination}

Vitamin $B_{12}$ content was determined by the method described in the Marck index (2001).One gram (1g) of insect sample was weighed into a $250 \mathrm{ml}$ volumetric flask. A known volume $(100 \mathrm{ml})$ of distilled water was added to the flask which was shaken for 45 minutes and made up to the mark with distilled water. The sample was then filtered into a $250 \mathrm{ml}$ beaker. To $20 \mathrm{mls}$ of the filtrate, $5 \mathrm{mls}$ of $1 \%$ sodium dithionite solution was added to decolorize the yellow colour. Standard cyanocobalamin with concentrations ranging from $0-10 \mu \mathrm{g} / \mathrm{ml}$ were prepared from stock cyanocobalamin and used to obtain a gradient factor. The absorbance of sample as well as standard were read at a wavelength of $445 \mathrm{~nm}$ on a Spectronic 21D spectrophotometer.

Vitamin $B_{12}$ in $\mu g / 100 g=$

Absorbance of sample $\times$ Gradient factor $\times$ Dilution factor weight of sample

\section{Vitamin $K$ determination}

Vitamin $K$ content was determined by the method described in the Rohde et al., (2007). Five gram $(5 \mathrm{~g})$ of insect sample was weighed in a $250 \mathrm{ml}$ beaker and $30 \mathrm{ml}$ of butyl alcohol was added. The mixture was thoroughly shaken to obtain a homogenous solution. The resulting mixture was filtered through a Whatman No. 42 filter paper into a volumetric flask and made up to the mark with butyl alcohol. An aliquot $(10 \mathrm{ml})$ of the sample was 
pipetted into a $30 \mathrm{ml}$ centrifuge tube and 3 drops of 2,4-dinitophenyl hydrazine was added to develop a blue colour which changed subsequently to a bluish green colour on addition of $3 \mathrm{ml}$ alcoholic ammonia. Standard solutions of vitamin K from $0-20 \mu \mathrm{g} / \mathrm{ml}$ were prepared to obtain a gradient factor. The absorbance of standards and sample were read on a Spectronic 21D spectrophotometer at a wavelength of $480 \mathrm{~nm}$.

Vitamin $\mathrm{K}$ in $\mu g / 100 \mathrm{~g}=$

$\frac{\text { Absorbance of sample } \times \text { Gradient factor } \times \text { Dilution factor }}{\text { weight of sample }}$

\section{Vitamin $B_{2}$ determination}

The determination of vitamin $B_{2}$ was carried out according to the specifications of British Pharmacopoedia (1988). Two grams (2g) of insect sample was weighed, crushed and dissolved in $20 \mathrm{ml}$ of glycerinated phosphate buffer. This was centrifuged for 10 minutes. The supernatant of the sample was obtained and $10 \mathrm{ml}$ of the sample was taken into a $100 \mathrm{ml}$ volumetric flask and made up to the mark with distilled water. Aliquots $(10 \mathrm{ml})$ of both test and standard solutions (Riboflavin) were pipetted into separate $50 \mathrm{ml}$ volumetric flasks and $2 \mathrm{ml}$ of $2 \%$ citric acid solution and $\mathrm{KMnO}_{4}$ were added to the sample and allowed to stand for 2 minutes. Finally $1 \mathrm{ml}$ of $\mathrm{H}_{2} \mathrm{O}_{2}$ was added to both flask containing the test and standard solutions and solutions were allowed to stand for 5 minutes. The absorbance of the test and standard solutions were taken at $450 \mathrm{~nm}$. Vitamin $B_{2}$ content was calculated using the formula

Vitamin $B_{2}$ in $m g / 2 g=\frac{A T}{A S}-0.085 \times \frac{W S}{500} \times 2$

Where AT is absorbance of Test

AS is absorbance of standard sample

WS is weight of standard sample

\section{Vitamin $C$ determination}

Vitamin C content was determined using the method described by Onwuka (2005). Five grams (5g) of the sample was homogenised in $45 \mathrm{ml}$ of distilled water. The suspension was then filtered. An aliquot $(5 \mathrm{ml})$ of the filtrate was measured into a $250 \mathrm{ml}$ conical flask and $0.1 \mathrm{ml}$ of glacial acetic acid was added. Dichlorophenol indophenol was titrated against the filtrate in the flask until the solution became faint pink. The titre value was taken and the vitamin $C$ content was then calculated.

\section{Determination of antinutrients}

The antinutrients determined in the insect samples were cyanogenic glycoside, phytate, tannins, oxalates and saponins.

\section{Determination of cyanogenic glycosides}

Alkaline Picrate method as described by Onwuka (2005) was used to determine the cyanogenic glycoside content of the samples. Five grams (5g) of insect sample was dissolved in $50 \mathrm{ml}$ distilled water in a conical flask and allowed to stay overnight to extract cyanide. The extract was filtered and the filtrate used for cyanide determination. To $1 \mathrm{ml}$ of sample filtrate, $4 \mathrm{ml}$ of alkaline picrate was added and allowed to incubate in a water bath for 5 minutes. After colour development (reddish brown colour), the absorbance was read at $490 \mathrm{~nm}$. The cyanide content was extrapolated from a cyanide standard curve.

\section{Determination of phytates}

Phytate determination was carried out using the method of Lolas and Markakis (1975). Two grams (2g) of sample was weighed into a $250 \mathrm{ml}$ conical flask. $100 \mathrm{ml}$ of $2 \%$ concentrated $\mathrm{HCl}$ was used to soak the sample in the conical flask for 3 hours. The mixture was filtered and $50 \mathrm{ml}$ of filtrate was placed in a $250 \mathrm{ml}$ beaker and $107 \mathrm{ml}$ of distilled water was added. A known volume $(10 \mathrm{ml})$ of $0.3 \%$ ammonium thiocyanate was added to the sample as indicator and titrated with iron III chloride solution which contained $1.95 \mathrm{mg}$ iron per $\mathrm{ml}$. Titration continued until a brownish yellow colour that persisted for 5 minutes was observed.

\section{Determination of tannins}

The Folin Denis Spectrophotometric method was employed as described by Onwuka (2005) to determine the tannin content of sample. One gram (1g) of each sample was dispersed in $10 \mathrm{ml}$ distilled water and shaken. The mixture was allowed to stand for 30minutes at room temperature. At the end of 30 minutes, the mixture was centrifuged and the extract obtained. An aliquot $(2.5 \mathrm{ml})$ of the supernatant (extract) was transferred into a $50 \mathrm{ml}$ 
volumetric flask. Similarly $2.5 \mathrm{ml}$ of standard tannic acid solution was transferred into a separate $50 \mathrm{ml}$ flask. A known volume $(1 \mathrm{ml})$ of Folin - Denis reagent was measured into each flask, followed by $2.5 \mathrm{ml}$ of $0.35 \%$ saturated $\mathrm{Na}_{2} \mathrm{CO}_{3}$ solution. The mixture was diluted to the mark in the flask $(50 \mathrm{ml})$ and incubated for 90minutes at room temperature. The absorbance was measured at 250nm using Jenway model 6000 Electronic Spectrophotometer. The tannin content was calculated as follows:

$\%$ Tannin $=A n / A s \times C \times 100 / W \times V f$

Where $A_{n}=$ absorbance of test sample, $A s=$ absorbance of standard solution. $C=$ concentration of standard solution, $W=$ weight of sample, $V f=$ total volume of extract.

\section{Determination of oxalates}

The titration method described by Day and Underwood (1986) was used to determine the oxalate content of the sample. One gram (1g) of each sample was weighed into a $100 \mathrm{ml}$ volumetric flask, where $75 \mathrm{ml}$ of $3 \mathrm{~N} \mathrm{H}_{2} \mathrm{SO}_{4}$ was added and stirred for 1 hour. The mixture was then filtered using whatman No 1 filter paper. From the filtrate, $25 \mathrm{ml}$ was taken and titrated against $0.1 \mathrm{~N} \mathrm{KMnO}_{4}$ solution, until a pink colour persisted for at least 30 seconds. The oxalate content was calculated as follows:

$$
\frac{T \times V m e(D F) \times 105}{M e \times M f}=m g / 100 \mathrm{~g} \text { Oxalate }
$$

where

$T=$ Titre of $\mathrm{KMnO}_{4}(\mathrm{ml})$, Vme is the volume mass equivalent $\left(1 \mathrm{~cm}^{3}\right.$ of $0.05 \mathrm{M} \mathrm{KMnO} 4$ solution is equivalent to $0.00225 \mathrm{~g}$ anhydrous oxalic acid)

$D f$ is the dilution factor $(V t / A=75 / 25=3)$ where $V t$ is the total volume of filtrate $(75 \mathrm{ml})$ and $A$ is the aliquot used for titration $(25 \mathrm{ml})$

$\mathrm{Me}$ is the molar equivalent of $\mathrm{KMnO}_{4}$ in oxalate and Weight of sample.

\section{Determination of saponins}

The gravimetric method of AOAC (1984) as modified by Ndamitsoet al., (2010) was used for saponin determination. Five grams $(5 \mathrm{~g})$ of insect sample was weighed into a thimble and transferred into a soxhlet extractor fitted with a condenser and a flat bottom flask. A known volume $(300 \mathrm{ml})$ of acetone was poured into the flask. The sample in the flask was exhaustively extracted of its lipids for 3 hours by heating the flask on a hot plate. This was the first extraction. Afterwards, a pre-weighed round bottomed flask containing $300 \mathrm{ml}$ of methanol was used to exhaustively extract the saponin for 3 hours. The methanol was distilled off and collected for further use and the flask reweighed. The difference between the final and initial weights of the flask represented the weight of saponin extracted.

\section{Statistical Analysis}

All values were expressed as mean \pm SEM for three determinations $(n=3)$. Statistical analyses was performed with one way analysis of variance (ANOVA) followed by Duncan's multiple range test using SPSS program 20.0. pvalues $\leq 0.05$ was considered to be significant.

\section{Results}

The proximate composition of the analysed insects is shown in Table 1. The moisture content of the insects ranged from $3.0 \pm 0.06 \%$ in moth caterpillar to $4.50 \pm 0.12 \%$ in termites. There was a significant difference $(p<0.05)$ between the moisture contents of the insects. The ash content ranged from $6.00 \pm 0.29 \%$ in crickets to $8.00 \pm$ $0.12 \%$ in termites. There was no significant difference ( $p>0.05$ ) in the ash content of cricket and grasshopper. The ash content of termite was significantly higher $(p<0.05)$ than those of moth caterpillar, cricket and grasshopper. The crude fibre content ranged from $5.96 \pm 0.33 \%$ in grasshopper to $9.30 \pm 0.17 \%$ in moth caterpillar. There was a significant difference $(p \leq 0.05)$ in the crude fibre contents of the insects. The crude fat content ranged from $6.50 \pm 0.12 \%$ in grasshopper to $40.83 \pm 0.03 \%$ in termite. There was no significant difference ( $p>0.05)$ in the crude fat content of cricket and grasshopper while the crude fat content of moth caterpillar (12.50 $\pm 0.06 \%$ ) was significantly ( $p<0.05)$ higher than those of cricket and grasshopper. The crude protein content of termite $(43.75 \pm 0.03 \%)$ was the lowest while that of grasshopper was the highest $(75.08 \pm 0.91 \%)$. There was a significant difference $(p<0.05)$ in the crude protein contents of the insects. The total carbohydrate content ranged from $2.94 \pm 0.61 \%$ in termites to $13.25 \pm 0.21 \%$ in moths. There was no significant difference ( $p>0.05)$ in the total 
Fountain Journal of Natural and Applied Sciences 2017; 6(1): 9-24

carbohydrate content of moth caterpillar and cricket. The metabolisable energy of the insects ranged from $391.83 \pm 0.35 \mathrm{Kcal} / 100 \mathrm{~g}$ in grasshopper to $554.00 \pm 0.34 \%$ in termites. There was a significant difference $(p<0.05)$ in the metabolisable energy of termites as compared to moth caterpillar, cricket and grasshopper.

Table 1: Proximate composition and energy content of selected insect species (\%)

\begin{tabular}{lllll}
\hline Parameters/Insects & $\begin{array}{l}\text { Termite } \\
\text { (Macrotermis } \\
\text { nigerensis) }\end{array}$ & $\begin{array}{l}\text { Moth } \\
\text { (Cirina forda) }\end{array}$ & $\begin{array}{l}\text { Cricket } \\
\text { (Gryllus } \\
\text { assimilis) }\end{array}$ & $\begin{array}{l}\text { Grasshopper } \\
\text { (Melanoplus foedus) }\end{array}$ \\
\hline Moisture & $4.50 \pm 0.12^{\mathrm{d}}$ & $3.00 \pm 0.06^{\mathrm{a}}$ & $3.50 \pm 0.01^{\mathrm{b}}$ & $4.00 \pm 0.03^{\mathrm{c}}$ \\
Ash & $8.00 \pm 0.12^{\mathrm{c}}$ & $7.00 \pm 0.35^{\mathrm{b}}$ & $6.00 \pm 0.29^{\mathrm{a}}$ & $6.17 \pm 0.17^{\mathrm{a}}$ \\
Crude Fibre & $6.76 \pm 0.03^{\mathrm{b}}$ & $9.30 \pm 0.17^{\mathrm{d}}$ & $8.28 \pm 0.01^{\mathrm{c}}$ & $5.96 \pm 0.33^{\mathrm{a}}$ \\
Crude Fat & $40.83 \pm 0.03^{\mathrm{c}}$ & $12.50 \pm 0.06^{\mathrm{b}}$ & $7.00 \pm 0.12^{\mathrm{a}}$ & $6.50 \pm 0.12^{\mathrm{a}}$ \\
Crude Protein & $43.75 \pm 0.03^{\mathrm{a}}$ & $64.05 \pm 0.01^{\mathrm{b}}$ & $71.04 \pm 0.01^{c}$ & $75.08 \pm 0.91^{\mathrm{d}}$ \\
Carbohydrates & $2.94 \pm 0.61^{\mathrm{a}}$ & $13.25 \pm 0.21^{\mathrm{c}}$ & $12.46 \pm 0.16^{\mathrm{c}}$ & $8.26 \pm 0.89^{\mathrm{b}}$ \\
$\begin{array}{l}\text { Metabolisable Energy } \\
\text { (Kcal/ 100g) }\end{array}$ & $554.00 \pm 3.40^{c}$ & $421.70 \pm 1.28^{\mathrm{b}}$ & $397.00 \pm 1.69^{\mathrm{a}}$ & $391.83 \pm 0.35^{\mathrm{a}}$ \\
\hline
\end{tabular}

Values are means of triplicate determinations \pm SEM

Values along rows with different superscript are significantly different $(p<0.05)$

Table 2 shows the mineral composition of the selected insects. Termite contained a higher amount of sodium $(2.36 \pm 0.25 \mathrm{mg} / 100 \mathrm{~g})$ as compared to Moth caterpillar $(0.23 \pm 0.01 \mathrm{mg} / 100 \mathrm{~g})$, Cricket $(0.42 \pm 0.01 \mathrm{mg} / 100 \mathrm{~g})$ and Grasshopper $(0.20 \pm$ $0.01 \mathrm{mg} / 100 \mathrm{~g}$ ). Grasshopper contained the highest concentration of copper $(0.07 \pm 0.00 \mathrm{mg} / 100 \mathrm{~g})$ while moth caterpillar contained the least amount of copper $(0.01 \pm 0.00 \mathrm{mg} / 100 \mathrm{~g})$. There was no significant difference ( $p>0.05$ ) in the concentration of calcium in termite, moth caterpillar and grasshopper. Cricket contained the least amount of calcium $(0.09 \pm 0.01 \mathrm{mg} / 100 \mathrm{~g})$. Moth caterpillar contained the highest amount of Magnesium (12.80 $\pm 0.03 \mathrm{mg} / 100 \mathrm{~g}$ ) while crickets contained the least amount of magnesium $(8.92 \pm 0.03 \mathrm{mg} / 100 \mathrm{~g})$. The concentration of iron was highest in grasshopper $(0.17 \pm 0.00 \mathrm{mg} / 100 \mathrm{~g})$ and lowest in moth caterpillar $(0.01 \pm 0.00 \mathrm{mg} / 100 \mathrm{~g})$. The concentration of zinc was significantly higher $(p<0.05)$ in cricket and grasshopper as compared to termite $(0.21 \pm$ $0.00 \mathrm{mg} / 100 \mathrm{~g})$ and moth caterpillar (0.11 \pm $0.00 \mathrm{mg} / 100 \mathrm{~g}$ ). The most abundant mineral in all the insects was potassium while chromium was the least abundant mineral in termite and grasshopper and manganese, the least abundant in moth caterpillar and cricket. The fatty acid profile of the insects is shown in Table 3. The results obtained show that

Table 2: Mineral composition of selected insect species ( $\mathrm{mg} / 100 \mathrm{~g})$

\begin{tabular}{lllll}
\hline $\begin{array}{l}\text { Insects/ } \\
\text { Parameters }\end{array}$ & $\begin{array}{l}\text { Termite (Macrotermis } \\
\text { nigerensis) }\end{array}$ & $\begin{array}{l}\text { Moth(Cirina } \\
\text { forda) }\end{array}$ & $\begin{array}{l}\text { Cricket } \\
\text { (Gryllus assimils) }\end{array}$ & $\begin{array}{l}\text { Grasshopper } \\
\text { (Melanoplus } \\
\text { foedus) }\end{array}$ \\
\hline $\mathrm{Na}$ & $2.36 \pm 0.25^{\mathrm{b}}$ & $0.23 \pm 0.01^{\mathrm{a}}$ & $0.42 \pm 0.01^{\mathrm{a}}$ & $0.20 \pm 0.01^{\mathrm{a}}$ \\
$\mathrm{K}$ & $416.65 \pm 34.50^{\mathrm{a}}$ & $381.21 \pm 8.69^{\mathrm{a}}$ & $367.133 \pm 14.4^{\mathrm{a}}$ & $367.02 \pm 16.97^{\mathrm{a}}$ \\
$\mathrm{Cu}$ & $0.03 \pm 0.00^{\mathrm{c}}$ & $0.01 \pm 0.00^{\mathrm{a}}$ & $0.02 \pm 0.00^{\mathrm{b}}$ & $0.07 \pm 0.00^{\mathrm{d}}$ \\
$\mathrm{Ca}$ & $0.21 \pm 0.01^{\mathrm{b}}$ & $0.21 \pm 0.02^{\mathrm{b}}$ & $0.09 \pm 0.01^{\mathrm{a}}$ & $0.22 \pm 0.02^{\mathrm{b}}$ \\
$\mathrm{Cr}$ & $0.01 \pm 0.00^{\mathrm{b}}$ & $0.01 \pm 0.00^{\mathrm{b}}$ & $0.01 \pm 0.00^{\mathrm{b}}$ & $0.00 \pm 0.00^{\mathrm{a}}$ \\
$\mathrm{Mg}$ & $10.66 \pm 0.11^{\mathrm{b}}$ & $12.80 \pm 0.04^{\mathrm{c}}$ & $8.92 \pm 0.03^{\mathrm{a}}$ & $10.77 \pm 0.03^{\mathrm{b}}$ \\
$\mathrm{Fe}$ & $0.14 \pm 0.00^{\mathrm{b}}$ & $0.01 \pm 0.00^{\mathrm{a}}$ & $0.15 \pm 0.00^{\mathrm{b}}$ & $0.17 \pm 0.00^{\mathrm{c}}$ \\
$\mathrm{Zn}$ & $0.21 \pm 0.00^{\mathrm{b}}$ & $0.11 \pm 0.00^{\mathrm{a}}$ & $0.24 \pm 0.01^{\mathrm{c}}$ & $0.24 \pm 0.00^{\mathrm{c}}$ \\
$\mathrm{Mn}$ & $0.13 \pm 0.00^{\mathrm{c}}$ & $0.00 \pm 0.00^{\mathrm{a}}$ & $0.00 \pm 0.00^{\mathrm{a}}$ & $0.01 \pm 0.00^{\mathrm{b}}$ \\
\hline
\end{tabular}

Values are means of triplicate determinations \pm SEM

Values along rows with different superscript are significantly different $(p<0.05)$ 
Fountain Journal of Natural and Applied Sciences 2017; 6(1): 9-24

Table 3: Fatty acid composition of insects (\%)

\begin{tabular}{|c|c|c|c|c|}
\hline Fatty acid & $\begin{array}{l}\text { Moth } \\
\text { caterpillar }\end{array}$ & Grasshopper & Termite & Cricket \\
\hline \multicolumn{5}{|l|}{ Hexanoic acid } \\
\hline (Caproic acid) & ND & ND & 0.47 & ND \\
\hline \multicolumn{5}{|l|}{ Octanoic acid } \\
\hline (Caprylic acid) & ND & ND & 1.21 & 1.27 \\
\hline \multicolumn{5}{|l|}{ Octanedioic acid } \\
\hline (Suberic acid) & ND & ND & 1.45 & ND \\
\hline Nonanoic acid & ND & ND & 1.34 & 1.57 \\
\hline \multicolumn{5}{|l|}{ Nonanedioic acid } \\
\hline (Azelaic acid) & 0.58 & 0.35 & 3.10 & ND \\
\hline Decanoic acid & ND & ND & ND & 4.99 \\
\hline \multicolumn{5}{|l|}{ Decanedioc acid } \\
\hline (Sebacic acid) & ND & ND & ND & 1.40 \\
\hline Heneicosanoic acid & ND & ND & ND & 0.93 \\
\hline \multicolumn{5}{|l|}{ Tetradecanoic acid } \\
\hline (Myristic acid) & 1.28 & 2.74 & 1.67 & 3.62 \\
\hline Pentadecanoic acid & ND & 0.70 & ND & 1.31 \\
\hline \multicolumn{5}{|l|}{ Heptadecanoicacid } \\
\hline (Margaric acid) & 4.10 & ND & 0.99 & 18.04 \\
\hline \multicolumn{5}{|l|}{ Hexadecanoic acid } \\
\hline (Palmitic acid) & 20.57 & 21.15 & 25.78 & 1.69 \\
\hline \multicolumn{5}{|l|}{ Octadecanoic acid } \\
\hline \multicolumn{5}{|l|}{ 11- Octadecenoic } \\
\hline acid (Vaccenic acid) & ND & 1.78 & 20.91 & 7.44 \\
\hline \multicolumn{5}{|l|}{ 5-Octadecenoic } \\
\hline acid & 1.11 & ND & ND & ND \\
\hline \multicolumn{5}{|l|}{$9,12,15-$} \\
\hline \multicolumn{5}{|l|}{ Octadecatrienoic } \\
\hline (Linolenic acid) & 28.69 & ND & ND & ND \\
\hline \multicolumn{5}{|l|}{$9,11-$} \\
\hline \multicolumn{5}{|l|}{ Octadecadienoic } \\
\hline acid & 1.32 & ND & 7.12 & ND \\
\hline \multicolumn{5}{|l|}{$9,12-$} \\
\hline \multicolumn{5}{|l|}{$\begin{array}{l}\text { Octadecadienoic } \\
\text { acid (Linoleic acid) }\end{array}$} \\
\hline & ND & 8.36 & ND & ND \\
\hline \multicolumn{5}{|l|}{ 9-Octadecenoic } \\
\hline acid (Oleic acid) & ND & 22.91 & ND & 6.66 \\
\hline \multicolumn{5}{|l|}{ Eicosanoic acid } \\
\hline (Arachidic acid) & ND & 1.17 & 1.07 & ND \\
\hline \multicolumn{5}{|l|}{13 - Docosenoic } \\
\hline acid & 13.08 & 10.22 & ND & 20.28 \\
\hline
\end{tabular}

\section{ND means Not detected}

crickets had the highest amount of myristic acid (3.62\%), margaric acid (18.04\%), and 13 -Docosenoic acid $20.28 \%$. Termite had the highest amount of palmitic acid $(25.78 \%)$ and vaccenic acid. Linolenic acid was only detected in Moth Caterpillar (28.69\%) while linoleic acid was only found in grasshopper $(8.36 \%)$. Oleic acid was present in Grasshopper 
Fountain Journal of Natural and Applied Sciences 2017; 6(1): 9-24

(22.91\%) and Cricket (6.66\%) but not detected in moth caterpillar and termite.

The vitamin composition of the selected insects is shown in Table 4. Vitamin $E$ was found to be the most abundant vitamin while vitamin $B_{2}$ was the least abundant in all the insects analysed. Grasshopper had the highest amount of Vitamin $A$ (4.970 \pm $0.081 \mathrm{mg} / 100 \mathrm{~g})$, Vitamin $B_{2}(0.790 \pm 0.460 \mathrm{mg} / 100 \mathrm{~g})$

Table 4: Vitamin compositions of selected insect species

\begin{tabular}{lllll}
\hline Insect/Parameter & $\begin{array}{l}\text { Termite } \\
\text { (Macrotermes } \\
\text { nigeriensis) }\end{array}$ & $\begin{array}{l}\text { Moth } \\
\text { (Cirinaforda) }\end{array}$ & $\begin{array}{l}\text { Cricket } \\
\text { (Gryllus } \\
\text { assimilis) }\end{array}$ & $\begin{array}{l}\text { Grasshopper } \\
\text { (Melanoplus } \\
\text { foedus) }\end{array}$
\end{tabular}

\begin{tabular}{|c|c|c|c|c|}
\hline VitaminA $(\mathrm{mg} / 100 \mathrm{~g})$ & $0.84 \pm 0.021^{b}$ & $0.243 \pm 0.028^{a}$ & $2.900 \pm 0.053^{c}$ & $4.970 \pm 0.081^{d}$ \\
\hline VitaminE $(\mathrm{g} / 100 \mathrm{~g})$ & $0.523 \pm 0.014^{b}$ & $0.363 \pm 0.020^{a}$ & $0.330 \pm 0.006^{a}$ & $0.480 \pm 0.023^{b}$ \\
\hline VitaminK $(g / 100 g)$ & $0.038 \pm 0.004^{a}$ & $0.023 \pm 0.003^{a}$ & $0.043 \pm 0.001^{a}$ & $0.034 \pm 0.001^{a}$ \\
\hline $\operatorname{Vitamin}_{12}(\mathrm{~g} / 100 \mathrm{~g})$ & $0.006 \pm 0.001^{b}$ & $0.002 \pm 0.001^{a}$ & $0.005 \pm 0.001^{b}$ & $0.003 \pm 0.001^{a}$ \\
\hline $\begin{array}{l}\text { Vitamin } B_{2} \\
(m g / 100 g)\end{array}$ & $0.190 \pm 0.110^{a}$ & ND & $0.230 \pm 0.080^{a}$ & $0.790 \pm 0.460^{b}$ \\
\hline VitaminC $(\mathrm{mg} / 100 \mathrm{~g})$ & $0.697 \pm 0.063^{a}$ & $1.013 \pm 0.063^{b}$ & $1.013 \pm 0.633^{b}$ & $1.330 \pm 0.110^{c}$ \\
\hline
\end{tabular}

Values are means of triplicate determinations \pm SEM

Values along rows with different superscript are significantly different $(p \leq 0.05)$

Table 5 shows the antinutrient composition of selected insects. The results showed that grasshopper had the highest concentration of phytate $(0.19 \pm 0.01 \mathrm{~g} / 100 \mathrm{~g})$. There was no significant difference in the tannin contents of all the insects ( $p>0.05)$. Grasshopper had the highest concentration of oxalate $(25.65 \pm 1.55 \mathrm{mg} / 100 \mathrm{~g})$

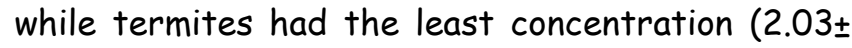
$0.04 \mathrm{mg} / 100 \mathrm{~g}$ ). There was no significant difference and Vitamin C (1.330 $\pm 0.110 \mathrm{mg} / 100 \mathrm{~g})$. There was no significant difference ( $p>0.05)$ in the vitamin $K$ contents of the insects. Termite was found to have the highest amount of vitamin $B_{12}$ (0.006 \pm $0.001 \mathrm{mg} / 100 \mathrm{~g}$ ) as compared to other insects analysed. Vitamin $B_{2}$ was not detected in Moth caterpillar.

( $p>0.05$ ) in the oxalate content of Moth Caterpillar and Cricket. Moth Caterpillar had the highest concentration of saponin $(1.21 \pm 0.11 \mathrm{~g} / 100 \mathrm{~g})$ while grasshopper had the least concentration ( $0.73 \pm$ $0.03 \mathrm{~g} / 100 \mathrm{~g}$ ). The cyanogenic glycoside content of Moth caterpillar and grasshopper were not significantly different $(p>0.05)$ and was higher than those of termite and cricket. Termite had the least concentration of cyanogenic glycoside (2.47 \pm $0.15 \mathrm{mg} / 100 \mathrm{~g}$ ).

Table 5: Antinutrient composition of selected insect species

\begin{tabular}{lllll}
\hline Insects/ Parameters & $\begin{array}{l}\text { Termite } \\
\text { (Macrotermes } \\
\text { nigeriensis) }\end{array}$ & $\begin{array}{l}\text { Moth (Cirina } \\
\text { forda) }\end{array}$ & $\begin{array}{l}\text { Cricket } \\
\text { (Gryllus } \\
\text { assimilis) }\end{array}$ & $\begin{array}{l}\text { Grasshopper } \\
\text { (Melanoplus } \\
\text { foedus) }\end{array}$ \\
\hline Phytates $(\mathrm{mg} / 100 \mathrm{~g})$ & $0.09 \pm 0.02^{\mathrm{a}}$ & $0.09 \pm 0.03^{\mathrm{a}}$ & $0.10 \pm 0.01^{\mathrm{a}}$ & $0.19 \pm 0.01^{\mathrm{b}}$ \\
Tannins $(\mathrm{mg} / 100 \mathrm{~g})$ & $0.47 \pm 0.06^{\mathrm{a}}$ & $0.48 \pm 0.09^{\mathrm{a}}$ & $0.49 \pm 0.08^{\mathrm{a}}$ & $0.52 \pm 0.01^{\mathrm{a}}$ \\
Oxalate $(\mathrm{mg} / 100 \mathrm{~g})$ & $2.03 \pm 0.04^{\mathrm{a}}$ & $20.25 \pm 0.20^{\mathrm{b}}$ & $20.93 \pm 0.93^{\mathrm{b}}$ & $25.65 \pm 1.55^{\mathrm{c}}$ \\
Saponins $(\mathrm{g} / 100 \mathrm{~g})$ & $0.99 \pm 0.18^{\mathrm{ab}}$ & $1.21 \pm 0.11^{\mathrm{b}}$ & $1.00 \pm 0.08^{\mathrm{ab}}$ & $0.73 \pm 0.05^{\mathrm{a}}$ \\
Cyanogenic & $2.47 \pm 0.15^{\mathrm{a}}$ & $11.75 \pm 0.18^{\mathrm{c}}$ & $3.76 \pm 0.27^{\mathrm{b}}$ & $11.27 \pm 0.04^{\mathrm{c}}$ \\
Glycosides $(\mathrm{mg} / 100 \mathrm{~g})$ & & & & \\
\hline
\end{tabular}

Values are means of triplicate determinations \pm SEM

Values along rows with different superscript are significantly different $(p<0.05)$ 


\section{Discussion}

Result from this study has shown that insects are good sources of protein. This is in agreement with several studies that the level of protein in insects are generally higher than those of conventional sources of proteins such as meat, dairy products and seeds (Defoliart, 2002; Banjo et al., 2006; Cerritos, 2009). The range of protein content of the selected insects (43.75-75.08\%) falls within the range reported by Ramos - Elorduy et al., (1997) (15- $81 \%$ ) as crude protein content of insects. The generally higher protein contents for cricket and grasshopper than those of moth caterpillar and termite suggest that insects in the order Orthoptera may be better sources of protein. This agrees with reports of van Huis (2003) that reported that the protein contents of insects in the order orthoptera range from 51 to $91 \%$, termite 25 to $65 \%$ and caterpillars 50 to $60 \%$. Proteins are macronutrients generally known to be body building nutrients, they are essential components of cells and they perform various functions as enzymes, hormones, transport molecules, defense molecules (immunoglobulins) and are involved in maintenance of osmotic and acid base balance (plasma proteins). Excess proteins can also be used as source of energy by the body. The high protein content found in the selected insects suggests that they may find relevance in the prevention of protein energy malnutrition.

The significantly higher $(p<0.05)$ crude fat in termite compared to other insects have shown that termite is a better source of fat. The lower fat content in grasshopper and cricket obtained in this study are low as compared to results of Ekop et al.,

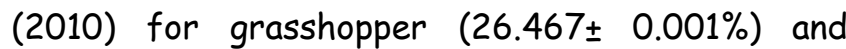
crickets $(26.467 \pm 0.001 \%)$. The lower fat contained in grasshopper and cricket may imply that insects in the order Isoptera and Lepidoptera are better sources of fat compared to those in order Orthoptera. Fats provide the body with energy and are essential in diets as they increase palatability of food. They also help in the transportation of fat soluble vitamins and provide the body with essential fatty acids required for healthy development of children and infants (Michaelsen et al., 2009). The high fat contents of termite may explain why they are the most commonly eaten insect in sub-Saharan Africa.

Insects have been reported to contain significant amount of fibre (van Huis et al., 2013). The high fibre content in insects is as a result of chitin, the form of insoluble fibre in insects derived from their exoskeleton. Chitin is a long polymer of $\mathrm{N}$ acetyl glucosamine, a major component of insect exoskeletons. Although Chitin may generally be considered as indigestible as it has a similar structure with cellulose, an enzyme chitinase, known to degrade chitin, has been found in human gastric juices (Paoletti et al., 2007). Bukken, (2005) stated that species with hard exoskeleton usually have high fibre contents. The crude fibre content of the insects were generally higher than those reported by Banjo et al., (2006) (1.10 - 3.40\%) and Ekop et al., (2010) for similar insects. Although Mbah and Elekima, (2007) and El Hassan et al., (2008) reported higher values of crude fibre in insects as compared to those obtained in this study. Variations in fibre contents of insects may be due to species differences. Dietary fibres are those components of food that cannot be broken down by human digestive system. They are known to play important roles in increasing stool bulk (aiding digestion). They also bind cholesterol and carcinogens thereby reducing plasma cholesterol and reducing the risk for coronary heart disease and cancers. Dietary fibres also slow down the rate of absorption of nutrients. This is of clinical importance because diets containing fibres slow down the rate of absorption of carbohydrate, consequently leading to a decrease in the rise in blood sugar and insulin levels if fibres are eaten with carbohydrate rich foods (Chaney, 2006). Although, there is an argument as to whether chitin plays similar roles as dietary fibre (Muzzarelli et al., 2001), insects may be good sources of fibre.

The moisture contents of insects in this work were generally low. The low moisture content of insects suggests that they may be kept for long periods without fear of deterioration or spoilage therefore they can be stored for food long when out season. The variation shown in the moisture content of the selected insects is expected as various reports have shown that insects vary widely in their 
moisture content. These can be attributed to species difference of the insects and also, processing methods of the insects. For example Ekop et al., (2010) reported for G. lucens (1.180 \pm $0.00 \%), H$. meles $(0.96 \pm 0.001 \%), R$. phoenicis $(1.130$ $\pm 0.001 \%)$ and Z.variegatus $(1.031 \pm 0.015 \%)$ but it was comparable with the moisture content of Anaphe veriata $(3.34 \%)$, Apis melifera (3.82\%), Cirina forda $(4.40 \%)$, reported by Banjo et al., (2006). The moisture content of insects analysed were also similar to those reported for Ruspolia differens $(4.5 \pm 0.2 \%)$ and Macrotermes falciger $(4.1 \pm 0.3 \%)$ (Siulapwa et al., 2014).

The ash content of a food material represents its total mineral content (Nielsen, 2002). The ash content of termite was higher than that of moth caterpillar, cricket and grasshopper, suggesting that termite may be a better source of minerals as compared to the other insects analysed. Although the ash content of insects analysed in this study were found to be higher than those reported by Banjo et al., (2006), the value reported by Ekop et al., (2010) is similar to that obtained in this study for cricket.

The generally low carbohydrate content found in the selected insects is in agreement with reports that insects are generally low in carbohydrate. Ekop et al., (2010) and El Hassan et al., (2008) reported low values for carbohydrate in insects while Siulapwa et al., (2014) reported high carbohydrate contents in Termite (Macrotermis falciger) and Caterpillar (Gonimbrasia belina). Results from this study therefore suggest that insects may not be good sources of carbohydrate.

The higher metabolisable energy of termite $(554.0 \pm 3.40 \mathrm{kcal} / 100 \mathrm{~g})$ can be attributed to the higher fat content of termite as compared to other selected insects. The metabolisable energy of the selected insects (391.83 $-554 \mathrm{kcal} / 100 \mathrm{~g})$ suggests that they could therefore contribute to the daily energy requirements of humans. The metabolisable energy of the selected insects were found to fall within ranges reported by Ramos - Elorduy et al., (1997) (293 - $762 \mathrm{Kcal} / 100 \mathrm{~g})$ and Siulapwa et al., (2014) $(385.0 \pm 0.4-810.2 \pm 0.6 \mathrm{kcal} / 100 \mathrm{~g})$.

The high potassium level of the selected insects is of significance because potassium is a cofactor in energy metabolism, glycogenesis and cell growth. Potassium has also been shown to play a role in the treatment of coronary heart disease as increased intake reduces blood pressure by increasing the excretion of sodium (Gibney et al., 2009). Low mineral content have been reported by other researchers (Ekop et al., 2010; Banjo et al., 2006). The presence of other minerals even though in low amounts could contribute to daily requirements of these minerals.

The selected insect species all contained both saturated and unsaturated fatty acids in relatively high amounts and this may explain why they have high metabolisable energy. The higher concentration of vaccenic acid in termite oil (20.91\%) is of significance. Vaccenic acid is a trans isomer of oleic acid and a naturally occurring trans fatty acid in ruminant fat. In mammals, transvaccenic acid is converted to conjugated linoleic acid which has been shown to have beneficial antioxidant and antitumour properties. Unlike industrial trans fatty acids produced by partial hydrogenation of oil, vaccenic acid has been shown to lower total cholesterol, LDL cholesterol and triglyceride levels in rodents (Field et al., 2009).

The high content of linolenic acid, an omega 3 polyunsaturated fatty, in moth caterpillar is also of significance because linolenic acid is an essential fatty acid that cannot be synthesized de novo from acetate (Gibney, 2009). Essential fatty acids are required for fluidity of membrane structure and for synthesis of eicosanoids. Deficiency of essential fatty acids is predominant in children and is characterised by scaly dermatitis, hair loss and poor wound healing. Oils rich in linolenic acid have been shown to reduce plasma levels of HDL and LDL cholesterol (Champe and Harvey, 2008).

The high brassidic acid content $(20.28 \%)$ of cricket oil means that consumption of oils from crickets may help to lower plasma concentration of LDL cholesterol and increase plasma HDL cholesterol hence reduce the risk of coronary heart disease. The presence of linoleic acid only in grasshopper oil shows that grasshopper oil can supply the dietary need of the essential fatty acid. Also the higher of ratio of unsaturated to saturated fatty acid in grasshopper is in conformity with the 
work of other researchers (Yang et al., 2006; Womeni et al., 2009; Kinyuru et al., 2011; Das and Mandal, 2013 and Chakravorty et al., 2014). Oils containing a higher percentage of unsaturated to saturated fatty acids are considered to be better for human health because dietary intake of these oils have been shown to reduce the risk of coronary heart disease (Chaney, 2006).

The selected insects contained various vitamins that meet their different RDA's. Vitamins are essential components of diet required in trace amounts to perform several cellular functions. The variation of the content of vitamin $A$ in various insects has been reported by various researchers (Banjo et al., 2006; van Huis et al., 2013). These variations may be as a result of differences in species, habitat and diet of the insects. The highest concentration of vitamin $A$, as seen in grasshopper can be attributed to the fact that they feed strictly on green grasses which are high in carotenoids (Bamaiyi and Aniesona, 2012). Insects have been shown to contain high amounts of vitamin $E$ (van Huis et al., 2013). The high amounts of vitamin $E$ are of great significance because vitamin $E$ is an important antioxidant that protects lipoproteins and cellular membranes from oxidative damage.

The insects were also found to contain high amounts of Vitamin $B_{12}$ (cobalamin), Vitamin $B_{2}$ (riboflavin) and vitamin $K$. This is in agreement with the study of Banjo et al., 2012, who reported that Rhynchophorus phoenicis and Macrotermes bellicosus were sources of these vitamins. Vitamin $B_{2}$ and $B_{12}$ are important precursors of coenzymes for enzymes of intermediary metabolism (Huskisson et al., 2007) while vitamin $K$ is required for the post translational formation of $\mathrm{V}$ carboxyl glutamyl residue in specific vitamin $K$ dependent proteins such as blood coagulation factors and osteocalcin (Uotila, 1990). Consumption of insects by humans may therefore contribute to the requirement of these vitamins required for the maintenance of various metabolic processes.

The antinutrient levels in all the insects analysed were generally low. The low antinutrients in the selected insects are in conformity with the reports of other researchers. Ekop et al., (2010) reported low levels of $\mathrm{HCN}$, oxalates, phytates and tannins in insects. The phytate compositions of insects were higher than those reported by Ekop et al., 2010, for cricket $(0.283 \mathrm{mg} / \mathrm{kg})$, yam beetle $(0.28 \mathrm{mg} / \mathrm{kg})$, palm weevil larva $(0.289 \mathrm{mg} / \mathrm{kg})$ and grasshopper $(0.281 \mathrm{mg} / \mathrm{kg})$. The presence of phytate in food reduces bioavailability of mineral elements like iron, calcium, magnesium, manganese and copper. Umaru et al., (2007), reported that a phytate diet of $1-6 \%$ over a long period may decrease the bioavailabilty of these mineral elements in monogastric animals. The phytate contents of insects in this report are below permissible levels of $22.10 \mathrm{mg} / 100 \mathrm{~g}$ (WHO, 2003) levels and therefore may not interfere with the absorption of mineral elements.

Oxalate was the most abundant antinutrient especially in moth caterpillar, cricket and grasshopper. Ekop et al., 2010 also reported higher values for oxalates as compared to other antinutrients they analysed in insects. This may suggest that oxalates may therefore be the predominant antinutrient in insects. The lethal dose of oxalate is between 200 to $500 \mathrm{mg} / 100 \mathrm{~g}$ (Pearson, 1973). The values obtained in this work are far below the lethal dose.

The presence of saponins and tannins reduce the protein digestibility of food by inhibiting the activity of trypsin and chymotrypsin. Since the amount of saponins and tannins were below the permissible limits $(48.05 \mathrm{mg} / 100 \mathrm{~g}$ and $76-90 \mathrm{~g} / \mathrm{kg}$ DM respectively) in all the insects analysed (Aletor, 1995: WHO, 2003), the presence of these antinutrients may not affect the digestibility of proteins obtained from these insects.

The levels of cyanogenic glycosides in all the insects were lower than the lethal dose for Hydrogen cyanide which is between $50-60 \mathrm{mg} / \mathrm{kg}$ body weight. Hydrogen cyanide is released on degradation of cyanogenic glycosides. Hydogen cyanide is a known inhibitor of cytochrome oxidase and therefore interferes with aerobic respiratory system (Onwuka 2005). Dietary intake of insects may not result to acute or chronic cyanide toxicity. Owing to the low antinutrient content of these insects, the use of insects as food may therefore not be detrimental to health. 


\section{Conclusion}

The insects analysed have been found to be good sources of proteins and fats. These insects also contain considerable amounts of vitamins, minerals and essential fatty acids required to maintain health and normal body functions. The high caloric value and protein content of insects suggest that they may find more relevance in the management of protein energy malnutrition. The use of insects as food is therefore encouraged.

\section{Conflict Of Interest}

The authors have declared no conflict of interest

\section{Acknowledgement}

The authors would like to acknowledge TETFUND for funds and technologists of the Department of Biochemistry, Federal University of Technology, Minna, Niger State, Nigeria for the technical contributions to this work

\section{References}

Adeyeye E.I., \& Awokunmi E.E. (2010). Chemical composition of female and Male Giant African Crickets, Brachytrupes membranaceous $L$. International Journal of Pharma and biosciences, 1(4), $125-136$.

Aletor, V.A. (1995). Nutrient and antinutrient components of some tropical leaf vegetables. Food Chemistry, 53(4), 375 - 379.

Alamu O.T., Amao, A.O, Nwokechi, C.I, Oke, O.A., \& Lawal, I.O. (2013).Diversity and Nutritional status of Edible Insects in Nigeria. International Journal of Biodiversity and Conservation, 5(4), $215-222$.

AOAC (1984). Official method of Analysis $14^{\text {th }}$ edition, Association of Official analytical Chemists, Washington D.C.

AOAC (1990). Official method of Analysis $15^{\text {th }}$ edition, Association of Official analytical Chemists, Washington D.C.

Bamaiyi P.H., \& Aniesona, A.T. (2012).Grasshoppers (ZonocerusVariegatus) as a Potential Global Alternative Source of Protein. Continental Journal of Food Sciences, 6 (2), 8 - 12.
Banjo A.D., Lawal O.A., \& Songonuga E.A. (2006). The Nutritional Value of Fourteen Species of Edible Insects in Southwestern Nigeria. African Journal of Biotechnology, 5 (3), 298 $-301$

Banjo, A.D., Aina, S.A., Lawal, O.A., Saliu, O.R., Odejayi, A.O., \& Owagboriaye, F.O. (2012). Proximate analysis of two common edible insects in Ijebu division, Southwestern Nigeria. Prime Research on Biotechnology, 2(4), 57- 62.

British pharmacopoedia (1988). Recommendation of Medicine London: Her Majesty's Stationary Office.

Bukkens, S.G.F. (2005). Insects in the Human diet: The Nutritional aspects. In M.G. Paoletti (Eds), Ecolological Implication of Minilivestock : Role of Rodents, Frogs, Snails, and Insects for Sustainable Development. New Hampshire : Science Publishers, pp 545 - 577.

Cerritos R. (2009).Insects as Food: An Ecological, Social and Economical Approach. CAB Reviews: Perspectives in Agriculture, Nutrition and Natural Resources, 4(27), 1-10.

Chakravorty, J., Ghosh, S., Jung, C., \& Meyer Rochow, V.B. (2014). Nutritional composition of Chondacrisrosea and Brachytrupes orientalis. Journal of Asian Pacific Entomology, 17 (3), 407 - 415.

Champe, P.C., \& Harvey. R.A. (2008). Lippincott's illustrated Reviews, Biochemistry, (4th ed.). New Delhi: Wolters Eluwer (India) Pvt. Ltd, pp 360- 364.

Chaney, S.G. (2006). Principles of Nutrition II: Micronutrients, In T.M. Devlin, (Eds.), Textbook of Biochemistry with Clinical Correlation ( $6^{\text {th }} \mathrm{Ed}$.). New York: John Wiley and Sons, pp 1093 - 1118.

Das, M., \& Mandal, S. (2013). Assessment of nutritional quality and antinutrient composition of two edible grasshoppers (Orthoptera : Acrididae) - A search for new food alternative. International Journal of Medicine and Pharmaceutical Science, 3(5), 31 -48 . 
Day, R.A. and Underwood A.L. (1986). Quantitative analysis ( $5^{\text {th }}$ ed.). Prentice, Hall publication, pp701.

Defoliart G.R. (1995). Edible Insects as minilivestock. Biodiversity and Conservation, 4(3). $306-321$.

Defoliart G.R. (2002). The Human use of Insects as a Food Resource: A Bibliographic Account in progress, Winconson, Madison, USA: University of Winconsin-Madison, pp 1-95.

Defoliart G.R, Dunkel, F.U. and Gracer, D. (2009). The Food Insect Newsletter. Salt lake city, Utah, USA. Aardvack Global Publishing, pp 414.

Ekop, E.A., Udoh, A.I., \& Akpan, P.E. (2010).Proximate and antinutrient composition of four edible insects in Akwa Ibom State Nigeria .World Journal of Applied Science and Technology, 2, 224-231.

El Hassan N.M., Ahmed S.Y., Hassan A.B., Eltayeb M.M., \& Babiker, E.E. (2008). Nutritional evaluation and Physiochemical properties of boiled and fried tree Locust. Pakistan Journal of Nutrition, 7(2), $325-329$,.

Fasoranti J.O., \& Ajiboye D.O. (1993) Some Edible Insects of Kwara State, Nigeria. American Entomologist, 39, $113-116$.

Field, C.J., Blewett, H.H., Procter, S., \& Vine, D. (2009). Human health benefits of vaccenic acid. Applied Physiology. Nutrition and Metabolism, 34 (5), 979-91.

Food and Agricultural Organisation of the United Nations (FAO) (2008). Locust Watch: Locust and the migratory pest group. Available form: http://www.fao.org/ng/locusts/en/info/index $\underline{h+m l}$

Food and Agricultural Organisation of the United Nations (FAO) (2015). The State of Food Insecurity in the World, Meeting the 2015 International Hunger Targets: taking stock of uneven Progress. Rome.
Gibney, J.M., Lanham, A.S., Aedin, C., \& Vorster, H.H. (2009). Introduction to Human Nutrition ( $\left.2^{\text {nd }} e d.\right)$. United Kingdom, :John Wiley and Sons Ltd. Publication, pp 74.

Heinrich M., \& Prieto J.M. (2008).Diet and Healthy ageing 2100: will we globalize local knowledge systems? Ageing Research Reviews, 7, 249274.

Huskisson E., Maggini S. \& Ruf, M. (2007). The role of vitamins and and minerals in energy metabolism and well being. Journal of International Medical Research, 35, 277 -289.

Iduwu, A.B., \& Modder W.W.D. (1996).Possible Control of the Stinking Grasshopper (Zonocerusvariegatus (L).Orthopthera: (Pyrogomorphidae) in Ondo State, through human consumption. The Nigerian Field, 61, 7 14.

Jacob A.A., Emenike F.A., Kayode A., Olusegun O., Uzoma A. \& Rukayat Q.K. (2013). Entomophagy : A panacea for protein - deficient Malnutrition and Food Insecurity in Nigeria. Journal of Agricultural Science, 5(6), 25 -31. Kagezi G.H., Kaib M.J., Nyeko P., \& Brandl R. (2010). Termites as Food in the Luhya community (Western Kenya).Sociobiology, 55(3), $381-845$.

Kinyuru, J., Kenji, G.M., Muhoho, S.N., \& Ayleko, M. (2011).Nutritional potential of Longhorn Grasshopper (Ruspolia differens) consumed in Siaya district Kenya. Journal of Agricultural Science and Technology, 12 (1), 32 -36.

Kourimska L., \& Adamkova A. (2016). Nutritional and sensory quality of insects. Nutrition and Food science Journal, 4, 22 -26.

Lolas, G.L., \& Markakis, P. (1975). Phytic acid and other phosphorus compounds of beans (Phaseolus vulgaris). Journal of Food Chemistry , 23, 13 -15.

Mbah C.E., \& Elekima G.O.V. (2007). Nutrient compositionof some terrestrial insects in Ahmadu Bello University, Samaru, Zaria, Nigeria. Science World Journal , 2(2), $17-20$. Michaelsen, K.F., Hope, C., Roos, N, Kaestel, P., Stougaard, M., Lauritzen, L., \& Molgaard, C. 
Fountain Journal of Natural and Applied Sciences 2017; 6(1): 9-24

(2009). Choice of foods and ingredients for moderately malnourished children 6 months to 5 years of age. Food and Nutrition bulletin, 20 (3), $343-404$

Muzzarelli, R.A.A., Terbojevich, M., Muzzarelli, C., Miliani, M., \& Francescangeli, O. (2001). Partial depolymerization of chitosan with the aid of papain. In: R.A.A. Muzzarelli (Eds.). Chitin Enzymology (pp 405 -414). Italy : Atec..

Ndamitso, M.M., Jacob, J.O., Idris, S., \& Jimoh, T. (2010). Prospects in the use of Ficuspolita as a local ruminant feed. African Journal of Biotechnology, 9 (21), $3116-3121$.

Nielsen S.S. (2002). Introduction to chemical analysis of foods, CBS Publishers 4596/1-A Daryagani, New Delhi 110032 (India),pp 95115.

Olaofe O., Arogudade L.A., Adeyeye E.I., \&Falusi O.M. (1998). Composition and food properties of variegated Grasshopper (Zonocerus vagiegatus). Tropical Science, 38, 233 - 237.

Omotoso, O.T. (2006). Nutritional Quality, Functional Properties and Antinutrient Compositions of the Larva of CirinaForda (Westwood) (Lepidoptera : Saturnidae). Journal of Zheijang University of Science, B 7(1), 51 - 55.

Onwuka GI (2005). Food analysis and Instrumentation theory and practice $\left(1^{\text {st }} e\right.$ d.) Napththali prints, Nigeria. 64 - 67, 98,140 145.

Osasona, A.I, \& Olaofe, O. (2010). Nutritional and functional properties of Cirina forda larva from Ado-Ekiti, Nigeria. African Journal of Food Sciences, 4(12), 775-777.

Paoletti, M.G., Norberto, L., Damini, R., \& Musumeci, S. (2007). Human gastric juice contains chitinasethat can degrade chitin. Annals of Nutrition and Metabolism, 51(3), 244 -251.

Pearson, D. (1973). The Chemical Analysis of Foods, ( $7^{\text {th }}$ ed.). London: Churchill Livingstone Press, pp 488 - 497.

Ramos - Elorduy, J. (1997). Insects: A sustainable source of food. Ecology of Food and Nutrition, $36,347-277$.

Rohde, L.E., Assis, M.C., \&Rabelo, E.R.. (2007). Dietary vitamin $K$ intake in elderly patients. Current Opinion in Clinical Nutrition and Metabolic Care, 10 (1), 1-5.

Siulapwa N., Mwambunay A., Lungu E., \& Sichilima W. (2014). Nutritional value of four common Edible insects in Zambia. International Journal of Science and Research, 3(60), 876 884.

The Marck Index (2001). Monograph No 10081 (13 ${ }^{\text {th }}$ ed.). New Jersey, USA :Marck and Co, White House Station, pp 1787.

Umaru, H.A., Adamu, R., Dahiru, R., \&Nadro, M.S. (2007). Levels of antinutrtional factors of some wild fruits in Northern Nigeria. African Journal of Biotechnology, 6(16), 1935 -1938.

Uotila, L. (1990). The Metabolic Functions and Mechanism of action of Vitamin K. Scandinavian and Laboratory Investigation, 50 (201), 109 -117.

van Huis, A. (2003). Insects as food in Sub-saharan Africa. Insect Science and it's application, 23(3), 163 - 185.

van Huis, A., Itterbeeck, V.J., Klunder, H., Mertens, E., Italloran, A., Mui, R.G., \&Vantomme, P. (2013). Edible Insects: future prospects for food security, FAO Forestry Paper 171, Rome, pp 67- 105.

WHO (2003). Post harvest and pressing Technology of staple food. Technical compendium of WHO agricultural science Bulletin, pp 88, $171-172$.

Womeni, H.M., Linder, M., Tiencheu, B., Mbrapo, F.T., Villeneuve, P., Fanni, J., \&Parmentier, M. (2009). Oils of insects and larvae consumed in Africa: potential sources of polyunsaturated fatty acids. OCL - Olèagineux, Corps Gras, Lipides, 16(4), 230-235.

Yang, L., Sirithon, S., \& Duo, L. (2006). Polyunsaturated fatty acid content of edible insects in Thailand. Journal of Food Lipids, 13 (3), $277-288$. 